\title{
STUDI DESKRIPTIF META ANALISIS PENGARUH BAHAN AJAR FISIKA DAN IPA TERHADAP PEMAHAMAN KONSEP SISWA
}

\author{
Venny Mulyana, Asrizal, Festiyed \\ Pascasarjana Pendidikan Fisika, FMIPA Universitas Negeri Padang \\ Email: vennymulyhana10@gmail.com
}

Diterima: 20 Januari 2021. Direvisi: 24 Februari 2021. Disetujui: 15 Maret 2021.

\begin{abstract}
Abstrak
Penelitian ini menyelidiki tentang pengaruh bahan ajar dalam pembelajaran IPA dan fisika terhadap pemahaman konseptual ditentukan melalui Effect Size (ES). Penelitian ini menggunakan metode studi deskriptif. Data penelitian diperoleh dari 20 jurnal tentang pengaruh bahan ajar fisika dan IPA terhadap pemahaman konsep seswa. Kajian didasarkan pada dua kategori, yaitu tingkat pendidikan dan jenis bahan ajar. Hasil penelitian menunjukkan bahwa; pertama, pengaruh bahan ajar dalam pembelajaran IPA dan fisika terhadap pemahaman konseptual berdasarkan tingkat pendidikan paling efektif di SMA dengan kategori tinggi. Kedua, berdasarkan jenis bahan ajar yang digunakan, pengaruh bahan ajar yang paling efektif adalah modul dengan kategori tinggi.
\end{abstract}

Kata Kunci: Meta Analisis, Bahan Ajar, Pemahaman Konsep.

\begin{abstract}
This study investigates the effect of teaching materials in science and physics learning on conceptual understanding determined through the Effect Size (ES). This research uses descriptive study method. The research data were obtained from 20 journals on the effect of physics and science teaching materials on understanding the concept of self. The study is based on two categories, namely the level of education and the type of teaching material. The results showed that; first, the influence of teaching materials in science and physics learning on conceptual understanding based on the level of education that is most effective in high school with a high category. Second, based on the type of teaching material used, the most effective effect of teaching materials is the module with a high category.
\end{abstract}

Keywords: Meta Analysis, Teaching Materials, Conceptual Understanding.

\section{PENDAHULUAN}

Pembelajaran adalah proses interaksi siswa dengan guru dan sumber belajar pada suatu lingkungan belajar (Fathurrohman, 2015). Pembelajaran di sekolah seharusnya tidak hanya terfokus pada penyampaian materi, namun juga perlu memperhatikan pemahaman siswa terhadap materi tersebut. Proses belajar dalam pembelajaran tidak hanya sekedar mengetahui dan menghafal fakta-fakta yang ada tetapi 
Mulyana., Asrizal., Festiyed. - Studi Deskriptif Meta Analisis...

juga harus memahami dan menguasai fakta-fakta tersebut sehingga menjadi satu pengetahuan yang utuh.

Hal ini sejalan dengan tujuan dari Pendidikan Nasional Indonesia yang tercantum dalam UU Sistem Pendidikan Nasional Nomor 20 Tahun 2003, yaitu untuk mengembangkan potensi siswa agar menjadi manusia beriman dan bertakwa kepada Tuhan Yang Maha Esa, berakhlak mulia, sehat, berilmu, cakap, kreatif, mandiri, dan menjadi warga negara yang demokratis, serta bertanggung jawab. Seorang guru dalam pembelajaran tidak hanya memiliki tugas untuk menyampaikan materi, tetapi juga harus melaksanaan pembelajaran yang bermakna. Gunawan et al (2016) menyatakan pembelajaran akan memberikan hasil yang baik jika didesain sesuai cara manusia belajar. Pembelajaran yang bermakna haruslah dilakukan pada semua bidang pelajaran termasuk di dalamnya ialah bidang fisika.

Peraturan Menteri tahun 2014 Nomor 059 menyatakan bahwa ilmu fisika merupakan (1) proses memperolah informasi melalui metode empiris (empirical method);
(2) informasi yang diperoleh melalui penyelidikan yang telah ditata secara logis dan sistematis; dan (3) suatu kombinasi proses berpikir kritis yang menghasilkan informasi yang dapat dipercaya dan valid. Fisika pada dasarnya merupakan pelajaran yang menarik dan menyenangkan. Hal ini dikarenakan banyaknya konsep fisika yang berhubungan dengan kehidupan sehari-hari. Namun, kenyataan di lapangan berkebalikan dengan pendapat tersebut. Siswa menganggap bahwa fisika merupakan pelajaran yang sulit, menakutkan, dan tidak ada hubungannya dengan kehidupan sehari-hari. Siswa sering merasa kesulitan menghubungkan materi yang dipelajari dengan penerapannya di kehidupan sehari-hari.

Pemahaman merupakan Salah satu aspek pada ranah kognitif yang dikemukakan oleh Bloom menyatakan pemahaman yaitu ketika siswa dihadapkan pada suatu komunikasi dan dapat menggunakan ide yang terkandung di dalamnya. Komunikasi yang dimaksud dapat dalam bentuk lisan atau tulisan dalam bentuk verbal atau simbolik. Pemahaman memerlukan kemampuan 
Mulyana., Asrizal., Festiyed. - Studi Deskriptif Meta Analisis...

menangkap makna dan arti dari suatu konsep (Sudjana, 2013).

Tipe hasil belajar pemahaman lebih tinggi satu tingkat dari tipe hasil belajar pengetahuan hafalan. Pemahaman memerlukan kemampuan menangkap makna atau arti dari suatu konsep. Untuk itu diperlukan adanya hubungan atau pertautan antara konsep dengan makna yang ada dalam konsep tersebut (Sudjana, 2013). Hubungan antara konsep dengan makna tersebut akan menghasilkan perubahan perilaku.

Rosser (dalam Dahar, 2011), menjelaskan konsep adalah suatu abstraksi yang mewakili suatu kelas objek, kejadian, kegiatan, atau hubungan yang mempunyai atribut yang sama. Konsep adalah abstraksiabstarksi yang berdasarkan pengalaman seseorang. Belajar konsep merupakan hasil utama pendidikan. Menurut Wingkel (dalam Bukhori, 2012), belajar konsep merupakan bentuk belajar yang dilakukan dengan mengadakan abstraksi yaitu dalam semua objek yang meliputi benda, kejadian, dan orang; hanya ditinjau aspek-aspek tertentu yang merupakan sebuah pengetahuan konseptual.

Pemahaman konsep siswa sangat kurang. Hal ini sesuai dengan hasil penelitian (Sandra et al., 2018) yang menyatakan bahwa kemampuan siswa dalam memahami konsep relatif rendah. Hasil penelitian Widiyanto, Sujarwanto, dan Prihaningtiyas (2018) juga menyatakan bahwa hasil pemahaman konsep siswa berada pada kategori lemah.

Pemahaman konsep siswa dapat ditingkatkan dengan melakukan beberapa upaya. Upaya yang dilakukan tidak hanya berfokus pada guru dan siswa saja, tetapi semua aspek yang ada pada proses belajar tersebut, salah satunya adalah penggunaan bahan ajar. Bahan ajar sebaiknya dikembangkan sendiri oleh guru secara inovatif. Hal ini karena guru yang lebih mengetahui karakteristik siswanya, kemampuan awal, daya serap, dan lain-lain.

Pengembangan bahan ajar dapat menjawab atau memecahkan masalah ataupun kesulitan dalam belajar. Keuntungan yang didapat dengan penerapan bahan ajar dalam pembelajaran menurut Santayasa 
Mulyana., Asrizal., Festiyed. - Studi Deskriptif Meta Analisis...

adalah sebagai berikut: (1)

meningkatkan motivasi siswa; (2) setelah dilakukan evaluasi, guru dan siswa mengetahui benar; (3) siswa mencapai hasil sesuai dengan kemampuannya; (4) bahan pelajaran terbagi lebih merata dalam satu semester, dan (5) pendidikan lebih berdaya guna, karena bahan ajar disusun menurut jenjang akademik.

Bahan ajar dirancang sebagai alat yang dapat membantu pendidik dan siswa dalam proses pembelajaran sehingga pembelajaran lebih efektif (Asrizal et al., 2018). Bahan ajar dirancang sebagai alat yang dapat membantu pendidik dan siswa dalam proses pembelajaran sehingga pembelajaran lebih efektif (Asrizal et al., 2018).

Penelitian ini dilakukan dengan beberapa tujuan. Yang pertama adalah untuk melihat seberapa besar pengaruh yang diberikan oleh bahan ajar fisika dan IPA terhadap pemahaman konsep yang ditinjau berdasarkan jenjang pendidikan. Kedua adalah untuk melihat besar pengaruh yang diberikan bahan ajar fisika dan IPA terhadap pemahaman konsep dalam pembelajaran yang ditinjau berdasarkan jenis bahan ajar.

\section{METODE}

Penelitian ini merupakan penelitian studi literatur yang berusaha memberikan gambaran mengenai Effect Size pengaruh bahan ajar fisika dan IPA terhadap pemahaman konsep siswa. Data diperoleh dari jurnal yang relevan dengan penelitian, yaitu jurnal mengenai pengaruh bahan ajar terhadap pemahaman konsep siswa. setelah dilakukan penelusuran terdapat 20 jurnal yang ditemukan sesusai dengan penelitian ini serta informasi data didalamnya yang dapat diolah.. Untuk menentukan besarnya ukuran efek dapat ditentukan, dalam parameter statistik seperti disajikan pada tabel 1 .

Setelah diperoleh Effect Size (ES), maka hasilnya dapat diinterpretasikan sesuai kriteria yang telah ditentukan jika ES $(0 \leq \mathrm{ES} \leq 0,2)$, maka masuk kategori rendah. Jika ES $(0,2 \leq \mathrm{ES} \leq$ $0,8)$, dikategorikan sedang. JIka $(\mathrm{ES} \geq$ $0,8)$ maka dikategorikan tinggi. 
Mulyana., Asrizal., Festiyed. - Studi Deskriptif Meta Analisis...

Tabel 1. Cara menentukan besarnya Effect Size

\begin{tabular}{cccc}
\hline No & Data Statistik & Rumus & Formula \\
\hline $\mathbf{1}$ & Rata-rata pada satu kelompok & $E S=\frac{\bar{x}_{\text {post }}-\bar{x}_{\text {pre }}}{S D_{\text {pre }}}$ & Fr-1 \\
$\mathbf{2}$ & $\begin{array}{c}\text { Rata-rata pada masingmasing } \\
\text { kelompok (two groups posttest only) }\end{array}$ & $E S=\frac{\bar{x}_{E}-\bar{x}_{C}}{S D_{C}}$ & Fr-2 \\
$\mathbf{3}$ & $\begin{array}{c}\text { Rata-rata pada masing } \\
\text { masingkelompok (two groups pre- } \\
\text { post tests) } \\
\text { Chi-Square }\end{array}$ & $E S=\frac{\left(\bar{x}_{\text {post }}-\bar{x}_{\text {pre }}\right)_{E}-\left(\bar{x}_{\text {post }}-\bar{x}_{\text {pre }}\right)_{C}}{\frac{S D_{\text {prec }}+S D_{\text {pre }}+S D_{\text {poss }}}{3}}$ & Fr-3 \\
$\mathbf{4}$ & thitung & $E S=\frac{2 r}{\sqrt{1-r^{2}} ; r}=\sqrt{\frac{x^{2}}{n}}$ & Fr-4 \\
& Nilai P & ES $=t \sqrt{\frac{1}{n_{E}}+\frac{1}{n_{C}}}$ & Fr-5 \\
$\mathbf{6}$ & CMA (Comperhensive Meta & Fr-6 \\
\hline
\end{tabular}

\section{HASIL DAN PEMBAHASAN}

Artikel yang dipilih adalah 20

artikel internasional dan nasional dan
Tabel 2 berisi kode, sumber serta Effect Size yang telah dianalisis dari ke 20 jurnal.

diberi kode J1 sampai dengan J20.

Tabel 2. Kode Jurnal, Sumber Jurnal dan Effect Size

\begin{tabular}{llll}
\hline Kode Jurnal & Sumber Jurnal & Effect Size & Formula \\
\hline J1 & (Astiti \& Yusuf., 2018) & 0.7 & Fr-5 \\
J2 & (Sakti., 2019) & 0.8 & Fr-1 \\
J3 & (Sandi et al., 2019) & 1.6 & Fr-5 \\
J4 & (Puspitasari et al., 2018) & 0.8 & Fr-5 \\
J5 & (Ummaeroh, Gusmania et al. 2019) & 0.7 & Fr-5 \\
J6 & (Aristini, Sudarma et al. 2017) & 5.1 & Fr-5 \\
J7 & (Fernanda, Ramli et al. 2015) & 0.5 & Fr-5 \\
J8 & (Rumansyah 2016) & 0.6 & Fr-5 \\
J9 & (Yulisa, Hakim et al. 2020) & 0.6 & Fr-5 \\
J10 & (Alfathy, Susanto et al. 2018) & 4.3 & Fr-5 \\
J11 & (Abdurrahman, Suyatna et al. 2018) & 0.8 & Fr-1 \\
J12 & (Taşlidere 2013) & 1.7 & Fr-2 \\
J13 & (Kahar, Wekke et al. 2018) & 1.1 & Fr-5 \\
J14 & (Yakob and Nafaida 2019) & 8.3 & Fr-5 \\
J15 & (Sadaghiani 2011) & 2.9 & Fr-1 \\
J16 & (Sari, Hasan et al. 2020) & Fr-5 \\
J17 & (Iwantara, Sadia et al. 2014) & 2.5 & Fr-1 \\
J18 & (Susilawati, Pramusinta et al. 2020) & 1.3 & Fr-5 \\
J19 & (Yonata, Prasetyo et al. 2020) & 0.89 & Fr-3 \\
J20 & (Yolanda, Gunawan et al. 2019) & 0.83 & Fr-3 \\
\hline
\end{tabular}


Mulyana., Asrizal., Festiyed. - Studi Deskriptif Meta Analisis...

Pengaruh bahan ajar fisika dan ajar fisika dan IPA memberikan IPA terhadap pemahaman konsep pengaruh yang tinggi pada jenjang siswa ditinjau dari jenjang Sekolah Menengah Pertama dan pendidikan

Sekolah Menengah Atas, yaitu

Berdasarkan hasil meta analisis dengan ukuran efek 1.56 dan 2.16. seperti ditunjukkan pada tabel 3 dapat Hal ini menunjukan bahwa bahan ajar dijelaskan bahwa pengaruh bahan ajar fisika dan IPA efektif jika digunakan fisika dan IPA terhadap pemahaman pada jenjang pendidikan SMA dan konsep siswa ditinjau dari jenjang SMP. pendidikan ditemukan bahwa bahan

Tabel 3. Data Hasil Ukuran Efek Berdasarkan Jenjang Pendidikan

\begin{tabular}{ccccc}
\hline $\begin{array}{c}\text { Jenjang } \\
\text { Pendidikan }\end{array}$ & $\begin{array}{c}\text { Kode } \\
\text { Jurnal }\end{array}$ & $\begin{array}{c}\text { Effect } \\
\text { Size }\end{array}$ & $\begin{array}{c}\text { Rata-Rata } \\
\text { Ukuran Efek }\end{array}$ & Kategori \\
\hline & J2 & 0.8 & & \\
J6 & 5.1 & & \\
J7 & 0.5 & & \\
SMP & J8 & 0.6 & 1.56 & \\
& J9 & 0.6 & & \\
J11 & 0.8 & & \\
& J17 & 2.5 & & \\
& J1 & 0.7 & & \\
J3 & 1.6 & & \\
J4 & 0.8 & & \\
J5 & 0.7 & & \\
J10 & 4.3 & & \\
SMA & J12 & 1.7 & & \\
& J13 & 1.1 & 2.16 & \\
& J14 & 8.3 & & \\
& J15 & 2.9 & & \\
& J16 & 3 & & \\
& J18 & 1.3 & & \\
& J19 & 0.9 & & \\
& J20 & 0.8 & & \\
& & &
\end{tabular}

Pengaruh bahan ajar fisika dan IPA terhadap pemahaman konsep siswa ditinjau dari jenis bahan ajar

Hasil kedua dari penelitian meta analisis ini terkait dengan pengaruh bahan ajar fisika dan IPA terhadap pemahaman konsep siswa ditinjau dari jenis bahan ajar. Rata-rata ukuran efek didapatkan dari perhitungan ukuran efek dari masing-masing artikel. Nilai rata-rata ukuran efek berdasarkan materi pembelajaran 
Mulyana., Asrizal., Festiyed. - Studi Deskriptif Meta Analisis...

yang digunakan dari 20 artikel jurnal nasional dan internasional dilihat pada Tabel 4.

Berdasarkan analisis hasil meta terkait pengaruh bahan ajar fisika dan IPA ditemukan bahwa pada semua jenis bahan ajar berada pada kategori tinggi, yaitu 2.55, 2.01 dan 1.14. Jadi dapat disimpulkan bahwa ukuran efek bahan ajar fisika dan IPA terhadap pemahaman konsep ditinjau dari jenis bahan ajar memberikan efek yang tinggi.

Tabel 4. Data Hasil Ukuran Efek Berdasarkan Mata Pelajaran

\begin{tabular}{|c|c|c|c|c|}
\hline Jenis bahan ajar & $\begin{array}{l}\text { Kode } \\
\text { Jurnal }\end{array}$ & $\begin{array}{l}\text { Effect } \\
\text { Size }\end{array}$ & $\begin{array}{c}\text { Rata-Rata } \\
\text { Ukuran Efek }\end{array}$ & Kategori \\
\hline \multirow{6}{*}{ Modul } & $\mathrm{J} 7$ & 0.5 & \multirow{6}{*}{2,55} & \multirow{6}{*}{ Tinggi } \\
\hline & J8 & 0.6 & & \\
\hline & $\mathrm{J} 12$ & 1.7 & & \\
\hline & $\mathrm{J} 14$ & 8.3 & & \\
\hline & $\mathrm{J} 15$ & 2.9 & & \\
\hline & $\mathrm{J} 18$ & 1.3 & & \\
\hline \multirow{9}{*}{ LKS } & $\mathrm{J} 1$ & 0.7 & \multirow{9}{*}{2,01} & \multirow{9}{*}{ Tinggi } \\
\hline & $\mathrm{J} 3$ & 1.6 & & \\
\hline & $\mathrm{J} 4$ & 0.8 & & \\
\hline & J5 & 0.7 & & \\
\hline & J6 & 5.1 & & \\
\hline & $\mathrm{J} 10$ & 4.3 & & \\
\hline & $\mathrm{J} 11$ & 0.8 & & \\
\hline & $\mathrm{J} 13$ & 1.1 & & \\
\hline & $\mathrm{J} 16$ & 3 & & \\
\hline \multirow{5}{*}{ Video } & $\mathrm{J} 2$ & 0.8 & \multirow{5}{*}{1.14} & \multirow{5}{*}{ Tinggi } \\
\hline & J9 & 0.6 & & \\
\hline & $\mathrm{J} 17$ & 2.5 & & \\
\hline & J19 & 0.9 & & \\
\hline & $\mathrm{J} 20$ & 0.8 & & \\
\hline
\end{tabular}

\section{Pembahasan}

Effect Size merupakan komponen penting dalam metaanalisis. Effect Size menunjukkan besarnya pengaruh dari suatu perlakuan hubungan antara dua variabel. Effect Size dapat menyajikan informasi dari hasil rangkuman jurnal yang dianalisis. Dengan menentukan Effect Size setiap penelitian maka rata-rata Effect Size secara keseluruhan dapat ditentukan. Peneliti melakukan perhitungan harga Effect Size dengan rumus Cohen.

Hasil penelitian ini dilakukan pada dua kategori yaitu efek bahan ajar fisika dan IPA terhadap pemahaman konsep berdasarkan 
Mulyana., Asrizal., Festiyed. - Studi Deskriptif Meta Analisis...

jenjang pendidikan (SMP dan SMA), dan efek bahan ajar fisika dan IPA terhadap pemahaman konsep berdasarkan jenis bahan ajar (modul, LKS, dan video). Hasil penelitian ini menunjukan bahwa penggunaan bahan ajar fisika dan IPA terhadap pemahaman konsep siswa.

Hasil pertama yang dicapai adalah bahan ajar fisika dan IPA terhadap pemahaman konsep berdasarkan jenjang pendidikan memberikan efek yang tinggi pada jenjang pendidikan SMP dan SMA. Hal ini berarti pada tiap jenjang pendidikan, bahan ajar memberi pengaruh terhadap pemahaman konsep siswa.

Hasil kedua yang dicapai adalah pengaruh bahan ajar fisika dan IPA terhadap pemahaman konsep ditinjau dari jenis bahan ajar yang terdiri dari 4 jenis bahan ajar, yaitu modul, LKS dan video. Dari hasil perhitungan, pengaruh bahan ajar fisika dan IPA terhadap pemahaman konsep pada setiap bahan ajar memiliki efek yang tinggi.

Secara keseluruhan bahan ajar fisika dan IPA memberikan efek positif yang tinggi dalam pemahaman konsep siswa. Hal ini menunjukan bahwa bahan ajar fisika dan IPA berbasis efektif digunakan disemua jenjang pendidikan, baik digunakan dengan berbagai jenis bahan ajar .

\section{KESIMPULAN}

Berdasarkan data yang telah dinyatakan dalam penelitian ini maka dapat dinyatakan dua hasil penelitian ini. Pertama pengaruh bahan ajar fisika dan IPA ditinjau dari jenjang pendidikan SMP dan SMA ajar memberikan pengaruh yang tinggi terhadap pemahaman konsep siswa. Kedua pengaruh bahan ajar fisika dan IPA ditinjau dari jenis bahan ajar memberikan pengaruh yang tinggi terhadap pemahaman konsep siswa.

Keterbatasan penelitian ini hanya menggunakan 20 jurnal nasional dan internasional. Penelitian selanjutnya perlu menambah jumlah jurmal yang di analisis.

\section{DAFTAR PUSTAKA}

Abdurrahman, A., Suyatna, A., Distrik, I. W., \& Herlina, K. (2018). Practicality and Effectiveness of Student'Worksheets Based on Ethno science to Improve Conceptual Understanding in 
Mulyana., Asrizal., Festiyed. - Studi Deskriptif Meta Analisis...

Rigid Body. International Journal of Advanced Engineering, Management and Science, 4(5), 240008.

Alfathy, R. M., Susanto, H., \& Marwoto, P. (2018). Penerapan Aktivitas Aesop's Berbantuan Guidance Worksheet untuk Meningkatkan Pemahaman Konsep Fisika dan Sikap Ilmiah. JIPVA (Jurnal Pendidikan IPA Veteran) 2(1): 48-57.

Aristini, N. K. D., Sudarma, I. K., \& Riastini, P. N. (2017). Pengembangan Lembar Kerja Siswa Berbasis Inkuiri untuk Pemahaman Konsep IPA Siswa. MIMBAR Undiksha 5(2).

Asrizal, A., Amran, A., Ananda, A., \& Festiyed, F. (2018, April). Effectiveness of adaptive contextual learning model of integrated science by integrating digital age literacy on grade VIII students. In IOP Conference Series: Materials Science and Engineering (Vol. 335, No. 1, p. 012067). IOP Publishing.

Astiti, K. A. and Y. H. M. Yusuf (2018). Pengaruh Penggunaan Bahan Ajar Berbasis Kontekstual terhadap Peningkatan Pemahaman Konsep Fisika Siswa Materi Suhu dan Kalor. Jurnal Fisika: Fisika Sains dan Aplikasinya 3(2): 185192.

Bukhori, M. A. F. (2013). Pembelajaran Berbasis Inkuiri Untuk Optimalisasi Pemahaman Konsep Fisika Pada Siswa Di SMA Negeri 4 Magelang, Jawa Tengah. Berkala Fisika Indonesia: Jurnal Ilmiah Fisika,
Pembelajaran dan Apliksinya, 4(1 \& 2), 11-21.

Dahar, R.W. (2011) . Teori-teori Belajar dan Pembelajaran. Jakarta : Erlangga

Fathurrohman, M. 2015. ModelModel Pembelajaran Inovatif. Jogjakarta: Ar-Ruzz Media.

Fernanda, R., Ramli, E., \& Ratnawulan, R. (2015). Pengaruh Penerapan Modul dalam Pembelajaran Discovery Learning terhadap Hasil Belajar Fisika Siswa Kelas X Semester 1 di SMAN 1 Kubung Kabupaten Solok. Pillar Of Physics Education 6(2).

Gunawan, G., Harjono, A., \& Imran, I. (2016). Pengaruh Multimedia Interaktif dan Gaya Belajar Terhadap Penguasaan Konsep Kalor Siswa. Jurnal Pendidikan Fisika Indonesia, 12(2), 118-125.

Iwantara, I. W., Sadia, I. W., \& Suma, K. (2014). Pengaruh penggunaan media video youtube dalam pembelajaran IPA terhadap motivasi belajar dan pemahaman konsep siswa. Jurnal Pendidikan dan Pembelajaran IPA Indonesia, 4(1).

Kahar, M. S., Wekke, I. S., \& Layn, M. R. (2018). Development of Problem Solving-Oriented Worksheet of Physics Learning In Senior High School. Jurnal Ilmiah Pendidikan Fisika Al-Biruni 7(2):79-90 .

Puspitasari, V., Wiyanto, W., \& Masturi, M. (2018). Implementasi Model Guided Discovery Learning Disertai Lks Multirepresentasi Berbasis Pemecahan Masalah 
Mulyana., Asrizal., Festiyed. - Studi Deskriptif Meta Analisis...

Untuk Meningkatkan Pemahaman Konsep Siswa. UPEJ Unnes Physics Education Journal 7(3): 18-27.

Rumansyah, M. (2016). Perbedaan pengaruh pembelajaran dengan menggunakan modul interaktif dan modul konvensional terhadap pemahaman konsep IPA. Jurnal Pendidikan Matematika dan Sains 4(1): 54-62.

Sadaghiani, H. R. (2011). Using multimedia learning modules in a hybrid-online course in electricity and magnetism. Physical Review Special Topics-Physics Education Research 7(1): 010102.

Sakti, I. (2019). Pengaruh Penggunaan Media Pembelajaran Berbasis Videoscribe Terhadap Pemahaman Konsep Fisika Siswa SMP Ittihad Makassar. PHYDAGOGIC Jurnal Fisika dan Pembelajarannya, 1(2), 49-54.

Sandi, T. S., Darvina, Y., \& Dewi, W. S. (2019). Pengaruh Lks Berorientasi Concept Attainment Pada Materi Momentum, Impuls Dan Getaran Harmonis Untuk Meningkatkan Pemahaman Konsep Fisika Siswa SMA. Pillar Of Physics Education 12(3).

Sandra, E., Tandililing, E., \& Oktavianty, E. (2018). Analisis Pemahaman Konsep Siswa pada Materi Hukum Newton di SMA Negeri 3 Bengkayang. Jurnal Pendidikan dan Pembelajaran Khatulistiwa 7(10).

Sari, G., Hasan, M., \& Mahidin, M. (2020, February). The development of student worksheet based on predict observe explain to increase students' conceptual understanding of the reaction rates. In Journal of Physics: Conference Series (Vol. 1460, No. 1, p. 012090). IOP Publishing.

Sudjana, N. (2013). Dasar-Dasar Proses Belajar Mengajar. Bandung: Sinar Baru Algensindo

Susilawati, S., Pramusinta, P., \& Saptaningrum, E. (2020). Penguasaan Konsep Siswa Melalui Sumber Belajar e-Modul Gerak Lurus dengan Software Flipbook Maker. UPEJ Unnes Physics Education Journal 9(1): 36-43.

Taşlidere, E. (2013). Effect of conceptual change oriented instruction on students' conceptual understanding and decreasing their misconceptions in DC electric circuits.Creative Education 4(4): 273-282.

Ummaeroh, R., Gusmania, Y., \& Hasibuan, N. H. (2019). Pengaruh Penggunaan Lks Berbasis Inkuiri Terhadap Pemahaman Konsep Matematis Siswa Kelas XI IPA SMA. PYTHAGORAS: Jurnal Program Studi Pendidikan Matematika, 8(2), 93-98.

Widiyanto, A., Sujarwanto, E., \& Prihaningtiyas, S. (2018, October). Analisis Pemahaman Konsep Peserta Didik dengan Instrumen Four Tier Diagnostic Test pada Materi Gelombang Mekanik. In Prosiding Seminar Nasional Multidisiplin (Vol. 1, pp. 138-146).

Yakob, M. and R. Nafaida (2019). Pengembangan Modul Lab Mandiri Roket Air Untuk Meningkatkan Pemahaman Konsep Dan Motivasi Belajar Siswa Pada Materi Hukum III Newton Di SMA Negeri 4 Langsa. 
Mulyana., Asrizal., Festiyed. - Studi Deskriptif Meta Analisis...

GRAVITASI: Jurnal Pendidikan Fisika dan Sains 2(02): 1-6.

Yolanda, S. E., Gunawan, G., \& Sutrio, S. (2019). Pengaruh Model Pembelajaran Inkuiri Terbimbing Berbantuan Video Kontekstual Terhadap Penguasaan Konsep Fisika Peserta Didik. Jurnal Pendidikan Fisika Dan Teknologi, 5(2), 341..

Yonata, B. P., Prasetyo, Z. K., \& Hastuti, P. W. (2020). Pengaruh
Metode Simulasi Berbantuan Media Video Terhadap Minat Belajar dan Pemahaman Konsep Peserta Didik. OPTIKA: Jurnal Pendidikan Fisika, 4(2), 73-84.

Yulisa, Y., Hakim, L., \& Lia, L. (2020). Pengaruh Video Pembelajaran Fisika Terhadap Pemahaman Konsep Siswa Smp. JURNAL LUMINOUS: Riset Ilmiah Pendidikan Fisika, 1(1), 3744. 